\title{
LAND USE AND LAND COVER MAP OF A SEMIARID REGION OF BRAZIL FOR METEOROLOGICAL AND CLIMATIC MODELS
}

\author{
RITA MARCIA DA SILVA PINTO VIEIRA, ANA PAULA MARTINS DO AMARAL CUNHA, \\ REGINA CÉLIA DOS SANTOS ALVALÁ, VITOR CELSO CARVALHO, SEBASTIÃO FERRAZ \\ NETO, MARCELO FRANCISCO SESTINI
}

\author{
Instituto Nacional de Pesquisas Espaciais (INPE), São José dos Campos, SP, Brasil \\ rita.marcia@inpe.br, ana.paula@cptec.inpe.br, regina.alvala@inpe.br, vitor@dsr.inpe.br, \\ sebastiao.neto@inpe.br, marcelof.sestini@inpe.br
}

Received May 2012 - Accepted September 2012

\begin{abstract}
An updated vegetation cover and land use map over a semiarid region of Brazil has been produced at a $1 \mathrm{~km}$ spatial resolution, using satellite data and remote sensing techniques, for application in climate modeling. The map presents the location and distribution of major vegetation types and non-vegetated land surface formations for the Northeast Brazil Region, which includes the semiarid region. In this study, Radambrasil and IBGE vegetation maps, a digital mosaic of $\mathrm{ETM}^{+}$Landsat 7, and TM Landsat 5 images from the period 1999-2000 were used. To update the map, the techniques of segmentation and unsupervised classification (ISOSEG) were applied. A total of 7 land cover and land use categories were mapped according to the "Simplified Simple Biosphere"(SSiB) model legend. This map shows that there has been a considerable increase in agricultural activities and pasture area. The vegetation in this region is an intricate combination of different life forms (e.g., trees and shrubs forming a closed cover) in this region. The semiarid region of Brazil is susceptible to desertification due to climatic and environmental conditions. This updated map should provide important input for regional stratification in climate studies.
\end{abstract}

Keywords: Land use change, Biogeophysical Model, Remote Sensing, Semiarid.

RESUMO: MAPA DE USO E COBERTURA DA TERRA DO SEMIÁRIDO DO BRASIL PARA MODELOS CLIMÁTICOS E METEOROLÓGICOS

Através da utilização de imagens digitais e técnicas de sensoriamento remoto, foi produzido um mapa de uso e cobertura da terra da região do semiárido do Brasil para aplicação em modelagem climática. O mapa apresenta a localização e distribuição dos principais tipos de vegetação e de formações não vegetacionais da superfície da terra para a região Nordeste do Brasil. Neste estudo foram utilizadas mapas de vegetação do Radambrasil e IBGE, mosaico digital de imagens Landsat $7 \mathrm{ETM}^{+}$e Landsat 5 TM do período de 1999-2000. Para atualizar o mapa foram aplicadas técnicas de segmentação e classificação não supervisionada (ISOSEG). Foram mapeadas um total de sete classes de uso e cobertura da terra, que foram compatibilizadas com a legenda do modelo de superfície "Simplified Simple Biosphere - SSiB" para o uso em modelos climáticos e meteorológicos. A vegetação nesta região é caracterizada por diversos padrões morfológicos, que dependem da localização geográfica e das condições climáticas. Os resultados obtidos pelo mapeamento indicam um aumento considerável nas atividades agrícolas e nas pastagens, e consequentemente, a redução da vegetação natural. Considerando que a região é susceptível a desertificação, devido as suas condições climáticas e ambientais, o mapa atualizado é de extrema importância para estudos que envolvam os impactos das mudanças dos usos e cobertura da terra no clima.

Palavras-chave: Mudança de uso da terra, Modelos biofísicos, Sensoriamento Remoto, Semiárido. 


\section{INTRODUCTION}

During the last few decades, the scientific community has dedicated efforts to evaluate the climatic impacts resulting from anthropogenic and natural land cover changes (Gao et al., 2003; Souza, 2006; Findell et al., 2007). Numerous studies using General Circulation Models and Regional Climate Models (GCMs and RCMs, respectively) have shown that climate is sensitive to the physical characteristics of vegetation and soil because these characteristics control the exchange of energy, water and momentum between the atmosphere and land surface (Xue and Shukla, 1993; Clark et al., 2001; Taylor et al., 2002; Oyama, 2002; Xue et al., 2004; Souza, 2006; Oliveira, 2008, Souza and Oyama, 2011). Moreover, the misrepresentation of land cover in atmospheric models may have negative impacts on the accuracy of weather forecasts and seasonal climate predictions (Wilson et al., 1985; Hall et al., 1995; Sud et al., 1996; DeFries et al., 1999; Champeaux et al., 2000; Kang et al., 2007, and others). Fenessy and Xue (1997) studied the impacts of the representation of vegetation on GCM simulations during summer. For the United States, their results showed that the use of a new vegetation map based on 1990 satellite and surface observations produced significant differences in both monthly and seasonal simulations of evaporation, surface air temperature, and precipitation. Champeaux et al. (2000) created a satellitederived land cover map for Western Europe for use in the operational French ARPEGE model. The new map contributed to improvements in weather forecasting. Errors, especially in the description of the diurnal cycle of temperature and relative humidity, were reduced. Therefore, to obtain more accurate simulations, it is necessary to provide realistic and up-to-date land cover spatial distribution data to the land surface schemes within atmospheric models.
Among the different land surface schemes developed to be coupled with atmospheric models, the Simplified Simple Biosphere Model (SSiB) (Xue et al., 1991) is used within the operational atmospheric models (GCM and RCM) of the Center for Weather Forecasts and Climate Studies (CPTEC). SSiB is a simplified version of the Simple Biosphere Model ( $\mathrm{SiB}$ ) (Sellers et al., 1986) and simulates the land-atmosphere interactions including radiative and turbulent processes, and biophysical control of transpiration. In $\mathrm{SSiB}$, a vegetation class is prescribed in each grid cell. Therefore, it is important to have accurate and updated vegetation maps. The main sources for the distribution of world vegetation types were the physiognomic classification of Kuchler (1983) and the land use database of Matthews (1984), which were used to form the original SSiB vegetation map (Fenesssy and Xue, 1997). SSiB uses the vegetation classification proposed by Dorman and Sellers (1989), which considers 11 natural biomes and 1 crop class (winter wheat) (Table 1). It is emphasized that the CPTEC operational system uses the global base of the vegetation information in the $\mathrm{SSiB}$ scheme coupled with GCM and RCM. This global base was produced at the University of Maryland (UMD) based on data from Pathfinder AVHRR Land (PAL) at a horizontal resolution of $1 \mathrm{~km}$. This map was prepared using 13 years of remote sensing data (1981-1994, De Fries et al. 1999; Hansen et al., 2000).

Cândido (2002) found that the vegetation map classification from UMD for the $\mathrm{SSiB}$ scheme classes produced inconsistencies in some regions of the Brazilian territory. For example, a large area of "caatinga" (Broadleaf Shrubs with Groundcover in SSiB legend) was found in parts of the Central Region and in Southern Brazil, and it led to excessively high temperature values in simulations performed by the RCM Eta coupled with $\mathrm{SSiB}$. Cândido used the natural vegetation map of Brazil (IBGE, 1993) to determine the extent of biomes that

Table 1- Classes compatibility of ProVeg, IBGE and SSiB

\begin{tabular}{lll}
\hline ProVeg-NEB & IBGE & SSiB \\
Broadleaf Evergreen Trees & Pioneer Formations and Ombrofila Forest & Tropical Rain forest \\
Deciduous Forest & $\begin{array}{l}\text { Seasonal Deciduous and Semi-deciduous } \\
\text { Forest }\end{array}$ & Broadleaf Deciduous Trees \\
Savanna (cerrado) & Savanna & Broadleaf Trees with Groundcover (Savanna) \\
Caatinga & Steppe and Steppic Savanna & Broadleaf Shrubs with Groundcover \\
Farming & Agricultural activities & Crops \\
Bare soil & Not mapped & Desert \\
Water bodies & Not mapped & Ice and water bodies
\end{tabular}


were incorrectly classified and created a new version of the vegetation map including only the natural biomes.

Lapola et al. (2008) developed a new world natural vegetation map at a horizontal resolution of 1 degree for use in global climate models. They used the Dorman and Sellers (1989) vegetation classification with the inclusion of a new biome, Tropical Seasonal Forest, which refers to both deciduous and semi-deciduous tropical forests. The natural vegetation maps of Ramankutty and Foley (1999) and of Matthews (1983), both at a horizontal resolution of 1 degree, were used to create a unified map. Other digital maps, such as that of the natural vegetation of Brazil (IBGE, 2004) and that of Alaska (Küchler, 1996), were also used. This new map was designed to accurately reproduce the large-scale distribution of the main vegetation types and regional details. Similar to the map of Cândido (2002), the map produced by Lapola et al. (2008) did not consider land use changes.

Even though there are other vegetation cover maps (Eva et al., 2004; Hodges, 2002 and others) available to use in meteorological and climate models, this work is part of an attempt to map the land cover and land use of the Brazilian territory with greater resolution (30 meters) than the existing global maps $(1 \mathrm{~km})$. This greater resolution allows the creation of maps with a more detailed scale (1:250 000).

The first part of the research involved developing a vegetation map of Legal Amazon (named Proveg-AMZ) with a spatial resolution of $1 \mathrm{~km}$ for the year 2000. The inputs for this map were obtained from a variety of sources: 1) the digital vegetation data of the RADAM-IBGE project; 2) the thematic data of deforestation generated by the Amazon Program (deforestation assessment in the Brazilian Legal Amazon PRODES); and 3) Landsat TM image mapping (Sestini et al., 2002). The second part of this research effort, Proveg-NEB, was created to improve the representation of land cover and land use spatial variability of Northeast Brazil (NEB). The semiarid region of NEB presents environmental problems of degradation (for example, desertification processes), and the affected areas may significantly expand as a result of human activities.

Thus, the goal of this paper is to present an updated vegetation map of NEB, including its semiarid region. The map also includes land cover changes, i.e., is not restricted to natural biomes, and is suitable to be coupled with the numerical models used at CPTEC and in other meteorological centers.

\section{SEMIARID REGION OF BRAZIL}

The study area (Figure 1) is located in the equatorial zone $\left(1-21^{\circ} \mathrm{S}, 32-49^{\circ} \mathrm{W}\right)$, covering an area of $1,797,123 \mathrm{~km}^{2}$ and representing approximately $20 \%$ of Brazilian territory. The limits of the study area were defined by the "Superintendência de Desenvolvimento do Nordeste (SUDENE)". The study area is covered by 86 Landsat images and is monitored in real time by CPTEC within the scope of the Climate Monitoring Program of the Northeast Region (PROCLIMA) (Souza at al., 2001).

The rainy season extends from February to May, when the Intertropical Convergence Zone (ITCZ) reaches its southernmost position (Kousky, 1979; Oyama and Nobre, 2004). Annual precipitation is less than $800 \mathrm{~mm}$ on average and is subject to large interannual variability. Part of this variability is explained by El Nino -Southern Oscillation (ENSO) related large-scale climate teleconnections (Hastenrath and Heller, 1977; Kousky et al., 1984, Kayano and Andreoli, 2006). Other factors, in addition to ENSO, that take relevant part in the interannual climate variability over NEB are associated with the tropical Atlantic SST variability. A SST variability mode in the tropical Atlantic, referred to as a SST dipole mode and

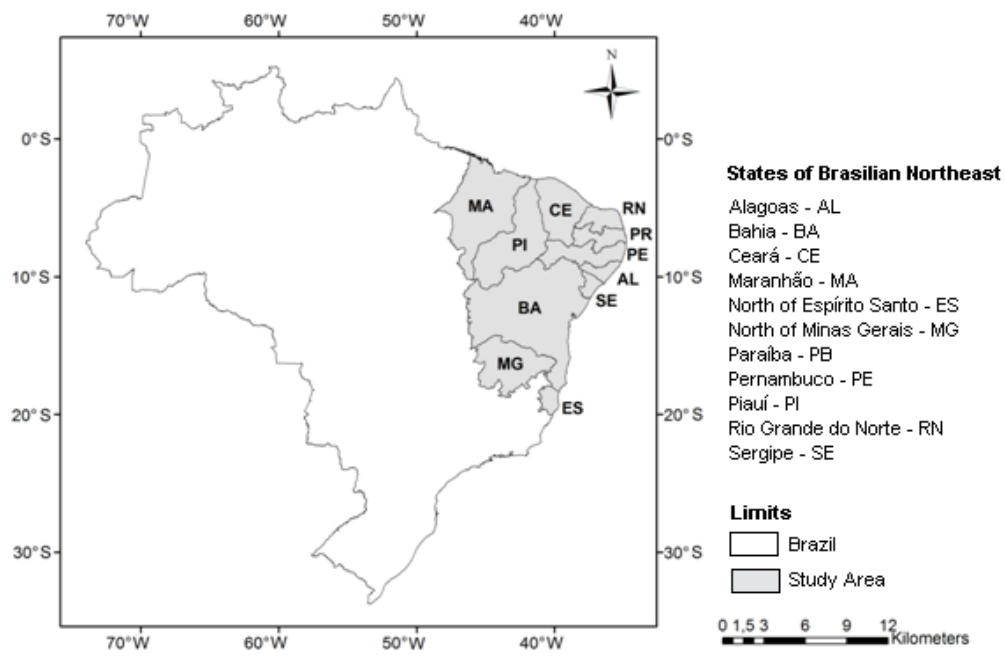

Figure 1 - Study Area. 
displaying an asymmetric SST anomaly pattern about the equator, has long been related to interannual climate variations over NEB (Hastenrath and Heller, 1977; Hastenrath, 1978; Moura and Shukla, 1981; Hastenrath, 1990; Hastenrath and Greischar, 1993; Souza et al., 2000, Kayano and Andreoli, 2006).

The soils present a large variation in type and association. Soils in the coastal zone are deep, low fertility Latosols; in the semiarid zone, the soils are shallow, high fertility Luvisols; and in the western portion, the soils are similar to those in the coastal zone.

There are different types of vegetation covering the region. Along the coastal areas, there are mangroves and dune vegetation, whereas places with tropical climate, such as the middle of the western region, are covered with savanna. In the western extreme of Northeast Brazil, where the climate is equatorial, the Amazonian Forest is found next to an area known as "Mata de Cocais" due to the abundance of babaçu (Orbignya oleifera Burret) and carnauba (Copernicia prunifera) palm-trees. A xeromorphic vegetation classified as Savanna Estepica (Broadleaf Shrubs with Perennial Groundcover), regionally known as caatinga (Veloso et al., 1991), covers an area of $558,526 \mathrm{~km}^{2}$ in the semiarid area. The semiarid climate dominates the regional landscape. During the dry season, the vegetation is dry and without foliage, the trees are sparse, and the soil is mostly uncovered, showing isolated shrubs and exposed roots.

In the semiarid areas of the NEB, rural areas in the interior are generally used for subsistence agriculture, primarily with crops of beans, manioc, potatoes and others (Cavalcanti, 1999).

\section{METHODS}

The methodology included two distinct steps: 1) the correspondence between the classes of the RADAMBRASIL (1:1000000) and IBGE (1:5000000) vegetation maps and those included in the SSiB model (Table 1) and 2) the mapping of the classes of land use and land cover. Because the number of classes in the SSiB model is limited, adaptations were made for some classes and different types were grouped into a single category. The farming class corresponding to type 12 of the $\mathrm{SSiB}$ model includes crops in different stages of growth, as well as pasture. The bare soil class, corresponding to the type 11 , includes areas with rock formations, sand dunes, bare soil, roads and urban areas.

It is important to note that the RADAMBRASIL and IBGE vegetation maps were used as auxiliary data, serving as a basis for compatibility of the legend and assisting the image interpretation process.

\subsection{Image classification techniques}

The methodology used in this study was developed by Sestini et al. (2002) and originally was used for mapping the area of Legal Amazon. The authors integrated data from PRODES and used automatic classification and visual interpretation of Landsat TM images. Enhancement techniques were also used to minimize possible errors concerning the interpretation of vegetation classes, mainly between short and open vegetation and anthropogenic areas. The image processing was also adopted to resolve conflict areas of vegetation. Thus, a number of different remote-sensing data sets were used to create the map presented in this work. Mosaics for each of the states of the region were composed of high resolution (30 and $60 \mathrm{~m}$ ) Landsat Thematic Mapper TM data from the years of 1999, 2000 and 2001 (Table 2). A total of 162 satellite images were used in the preparation of the vegetation cover map.

The RADAMBRASIL and the IBGE vegetation map (1:1000000 and 1:5000000, respectively) were adjusted over the satellite images and used as auxiliary data. The images were classified by means of unsupervised classification, using the Isoseg algorithm. Unsupervised classification is a method that examines a large number of unknown pixels and divides them into a number of classes based on natural groupings present in the image values. The classification process can be described briefly as follows: first, the user provides a percentage acceptance threshold. This threshold defines the maximum Mahalanobis distance (Richards, 1995) from which regions can be from the center of one class and still be considered as belonging to that class. It also determines the number of class "clusters" detected by the algorithm. Iteratively, the classifier removes from the list all regions with a Mahalanobis distance smaller than the acceptance threshold. The user controls the level of detail through the acceptance threshold: more classes for higher significance levels $(<80 \%)$ or fewer classes for lower significance levels (>95\%). After testing several thresholds, the threshold of $90 \%$ was accepted, which appropriately separated classes without creating redundancy.

The images for each state of the RADAMBRASIL and IBGE maps and the corresponding SSiB classes were re-sampled to $1 \mathrm{~km}$ resolution. The zonal majority operator was used, where by the value in all geographical locations within a region is equal to the most frequently found value in that region (Barbosa et al., 1998).

\section{RESULTS}

Figure 2 illustrates the correspondence between the vegetation classes of the IBGE map (IBGE, 1993) and the classes of the SSiB model. The areas of ecological tension or 
Table 2 - Summary of the data sets used for the image mosaics

\begin{tabular}{ccccc}
\hline State & Dates & Cloud Cover & Number of images & Resolution \\
& & $(\%)$ & 22 & $(\mathbf{m})$ \\
MA & 2000 & 2 & 21 & 60 \\
PI & $1999-2000$ & 5 & 11 & 30 \\
CE & $1999-2000$ & 5 & 07 & 30 \\
RN & 2002 & 6 & 06 & 15 \\
PB & $1999-2000$ & 6 & 09 & 30 \\
PE & $1999-2000$ & 5 & 05 & 30 \\
AL & $1999-2000$ & 5 & 03 & 30 \\
SE & $1999-2000$ & 3 & 36 & 30 \\
BA & $1999-2001$ & 2 & 36 & 30 \\
MG & 2001 & 0 & 06 & 30 \\
ES & 2001 & 0 & & \\
\hline
\end{tabular}

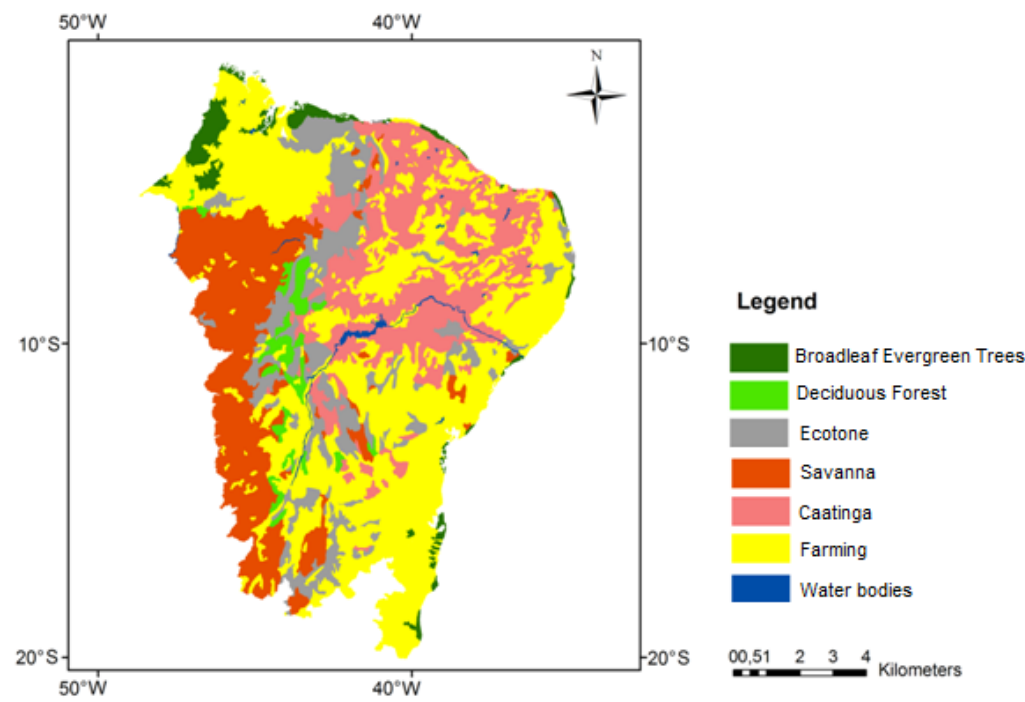

Figure 2 - IBGE map with SSiB classes.

contact are defined as those that combine two or more types of vegetation cover with physiognomic structures that are similar or dissimilar. The contacts map depends on the type and scale (Veloso et al., 1991).

When data or maps at finer spatial resolutions are used, the contacts can be resolved. It is very important to resolve the contact areas because they may contain significant areas of human activities (or anthropized areas). Mapping these areas, for example, enables investigation about the possible effects and feedbacks induced by anthropogenic land use change on the climate.
The contact areas in the IBGE vegetation map were classified and resolved by image segmentation, visual interpretation and information from experts in semiarid environments (Figure 3). The ecological tension areas in the IBGE map are extensive, corresponding to $20 \%$ of the total area of natural vegetation (Table 3 ). The land use and land cover map of NEB, including the semiarid region, is shown in Figure 4.

In Table 3, Column 2 shows the amount of area covered by natural vegetation without anthropogenic land use in the IBGE map (1993), while Column 3 shows the area estimates for each vegetation type with anthropogenic land use in the 
Table 3 - The distribution of land cover classes across Northeast.

\begin{tabular}{|c|c|c|c|c|c|c|}
\hline \multirow[t]{2}{*}{$\begin{array}{l}\text { Land Cover and } \\
\text { Land Use }\end{array}$} & \multicolumn{2}{|c|}{$\begin{array}{l}\text { IBGE classes } \\
\qquad(1993)\end{array}$} & \multicolumn{2}{|c|}{$\begin{array}{c}\text { Natural vegetation and } \\
\text { anthropogenic land use } \\
\text { (IBGE, 1993) }\end{array}$} & \multicolumn{2}{|c|}{$\begin{array}{l}\text { ProVeg-NEB classes } \\
\qquad(2000)\end{array}$} \\
\hline & $\left(\mathrm{km}^{2}\right)$ & $(\%)$ & $\left(\mathrm{km}^{2}\right)$ & $(\%)$ & $\left(\mathrm{km}^{2}\right)$ & $(\%)$ \\
\hline Broadleaf & 255.25 & 14.34 & 53.02 & 2.96 & 102.034 & 5.68 \\
\hline \multicolumn{7}{|l|}{ Evergreen Trees } \\
\hline Deciduous Forest & 284.26 & 15.96 & 45.60 & 2.54 & 114.79 & 6.39 \\
\hline Savanna & 344.56 & 19.34 & 310.54 & 17.32 & 241.40 & 13.43 \\
\hline Caatinga & 558.53 & 31.36 & 352.36 & 19.65 & 273.59 & 15.22 \\
\hline Ecotone & 338.87 & 19.00 & 221.57 & 12.36 & solved & - \\
\hline Bare soil & - & - & - & - & 23.19 & 1.29 \\
\hline Farming & - & - & 798.38 & 44.50 & $1,024.62$ & 57.01 \\
\hline Water bodies & - & - & 11.92 & 0.66 & 17.50 & 0.97 \\
\hline
\end{tabular}

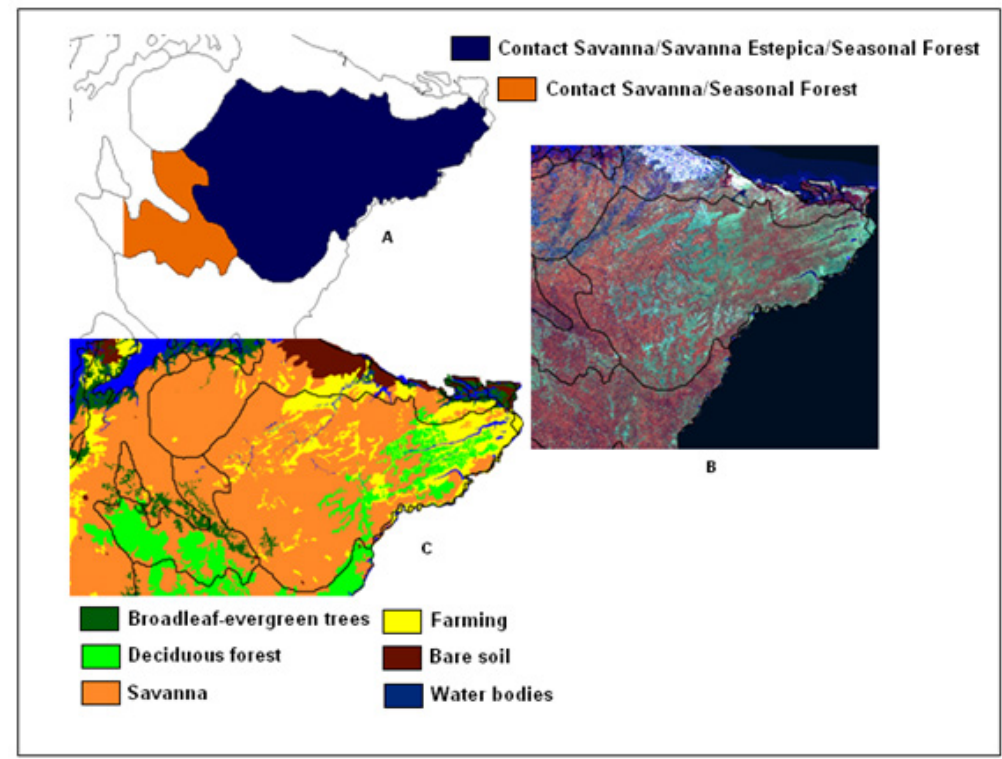

Figure 3 - Contact areas in the IBGE vegetation map

IBGE map (1993). The different types of land cover mapped by the Proveg-NEB project are shown in Column 4. The results obtained from the Proveg-NEB map show that many classes of natural vegetation considered in the IBGE map were degraded with a consequent reduction in area.

Comparing the new vegetation map (2000) with the map of IBGE (1993), it can be noticed that a large savanna area was devastated, meaning that approximately $22 \%$ of the natural vegetation has been degraded. In addition, in 1993, the caatinga occupied $352,364 \mathrm{~km}^{2}$, while by 2000 it had been reduced to
$273,590 \mathrm{~km}^{2}$, meaning that there was a loss of approximately $22 \%$ within a 7 year period. Combined, these two ecosystems, which accounted for $37 \%$ in 1993 , have been reduced to $29 \%$. However, the areas of Broadleaf Evergreen Trees $\left(53,023 \mathrm{~km}^{2}\right)$ and Deciduous Forest $\left(45,596 \mathrm{~km}^{2}\right)$ increased to $102,034 \mathrm{~km}^{2}$ and $114,790 \mathrm{~km}^{2}$, respectively. These increases were due to the physiognomic-structural interpretation of the conflict areas $\left(221,573 \mathrm{~km}^{2}\right)$.

An analysis of Figure 4 and Table 3 reveals that there is a notable increase in the extent of the Farming class in the 


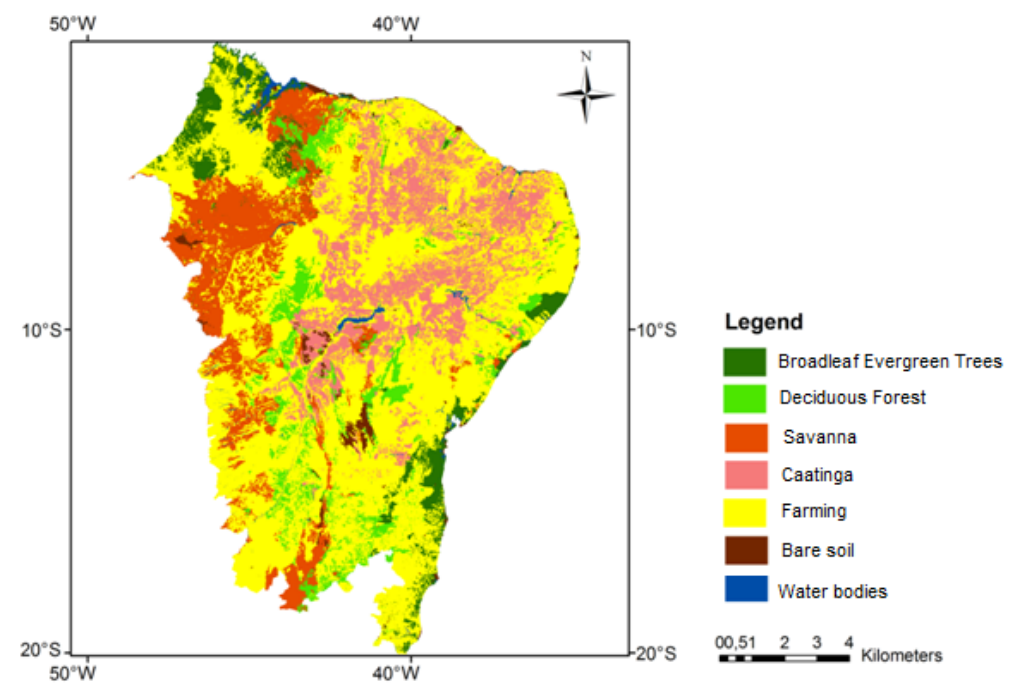

Figure 4 - Land use and land cover map of the Brazilian Northeast (ProVeg-NEB map).

updated map $\left(1,024,621 \mathrm{~km}^{2}\right)$ compared to the IBGE map $\left(798,376 \mathrm{~km}^{2}\right)$. These results correspond with those found in the 2006 agricultural census of the IBGE, which stated that the crop area has increased 20\% since the 1996 census. This increase may have occurred due to the progressive integration of grain production and intensive livestock production within the world market (IBGE, 2010). Thus, the increase of crop area can aggravate the problem of local desertification, although other factors must be incorporated into the analyses to validate this hypothesis.

The areas of bare soil, which were not identified in the RADAMBRASIL and IBGE maps, occupy an area of 23,190 $\mathrm{km}^{2}$, corresponding to more than $1 \%$ of the total area. The areas of highland and rupestrian fields were converted to bare soil, based on the physiognomic characteristics and spectral responses. Bare soil regions have a characteristic spectral signature in Landsat satellite images and a higher albedo than vegetated areas, as evaluated by Cunha et al. (2009). The increase in surface albedo reduces the radiation balance in the top of the atmosphere, inducing subsidence anomalies to maintain thermal equilibrium and, consequently, reducing moisture convergence in low levels, as highlighted by Oyama and Nobre (2004). Thus, it is important to include bare soil areas in maps for surface models because the processes of biosphereatmosphere interaction for bare soil areas are distinct from those for land covered by vegetation.

The percentages of vegetation cover and land use in the study area are shown in Figure 5. The results indicate that the State of Bahia incorporates the largest number of classes, both in terms of vegetation cover and in terms of use and occupation; this result is expected because it is the largest state in the Northeast region. The state covers $566,049 \mathrm{~km}^{2}$, corresponding to $38 \%$ of the total study area and $6.9 \%$ of the country. Additionally, the area covered by water in the study area $(50 \%)$ is concentrated in the State of Bahia. The distribution of land cover types varies in proportion to the area of each state in the region.

In general, the land use and land cover map presented here shows, on a regional scale, the conversion of natural vegetation of caatinga and Savanna areas into farming regions (including crop and pasture lands) in the NEB region.

This map is also compared with the default map (not shown) previously used in surface models coupled with the numerical models at CPTEC/INPE. It was observed that in NEB, some classes of natural vegetation were over-estimated. The area of caatinga, for example, was more than $78 \%$ of the updated map. Thus, the inconsistencies were detected and resolved, which was possible due to the spatial accuracy of the Landsat data $(30 \mathrm{~m})$.

\section{DISCUSSION AND CONCLUSIONS}

The land use and land cover map of the semiarid region of Brazil for meteorological and climatic models presented here shows that $57 \%$ of NEB territory represents anthropic areas, which were previously occupied primarily by caatinga. In addition to anthropic areas and natural vegetation, the map also includes areas covered by bare soil and bodies of water.

It was not possible to compare the area values of land cover change with others publications in the northeast of Brazil, because there is not any other map that covers the whole northeast region and also includes the same classes. However, analyzing regional and Biomes maps (MMA/PROBIO, 2007; IBAMA, 2010) it was noted an accelerated degradation of the natural vegetation corroborating the results presented in this study. 


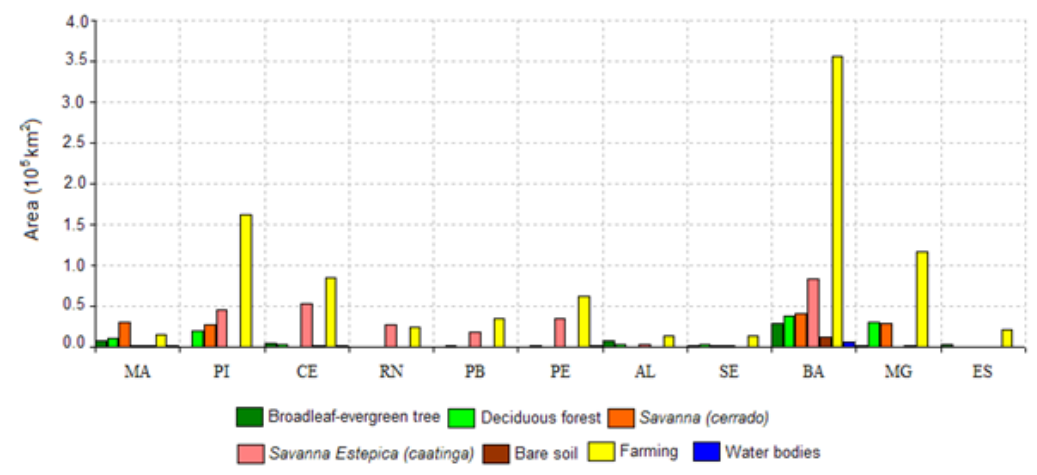

Figure 5 - Area of vegetation cover and land use.

In the context of meteorological modeling, Souza (2006) evaluated the impact of the use of an updated vegetation map for the semiarid region of Brazil on the seasonal climate using the regional model ETA coupled with the SSiB scheme (ETA/ $\mathrm{SSiB})$. The experiment considered a previous version of the map presented here. The principal difference between the map used in the simulations and the one used previously in the model was the replacement of caatinga and Savanna by farming (crop/ pasture), considered by Souza as corresponding to biome type 12 of Dorman and Sellers (1989). These changes in vegetation cover impacted the simulations of the seasonal climate, mainly in precipitation over the regions (and adjacent areas) of modified vegetation. The results showed that the degradation of small scale areas can also impact climate on both local and seasonal scales (summer and autumn).

The map presented here was originally developed to provide a more detailed representation of the surface in the CPTEC GCM for weather and climate forecasting. However, because the initial spatial resolution is $30 \mathrm{~m}$, the map can be easily adaptable to other surface schemes coupled with atmospheric models.

An assessment concerning this new map is being carried out to investigate the potential climatic impacts resulting from changes in vegetation cover due to human activities or natural processes in the semiarid region of Brazil. The evaluation of land use and land cover dynamics and its climatic implications are essential for decision makers, for public policies and for an integrated management plan of an important region of Brazil.

The four desertification areas of the region are currently being mapped, which is an effort that includes a multitemporal evaluation. It is emphasized that the land use and land cover map of the semiarid region presented here is in the process of being updated to include the most recent data and a finer resolution for crop lands. This initiative must be maintained to support the high demand for a more detailed representation of the Earth's surface, which is essential for the new surface models in development in Brazil.
Compared to IBGE and RADAM maps, the present map used finer spatial resolution data and it allowed more realistic mapping of the land cover/land use spatial distribution as well as the elucidation of the areas of ecological tension.

Although this map was based on 1999-2001 satellite images, there are no maps with recent satellite data for the same studied region. There are Biomes maps developed with different methodologies and also the legend is not compatible for surface models, such as the ones used by CPTEC. Besides that the map presented in this study is being updated with more recent satellite images.

In the future, it will be necessary to identify the types of crops in the study area. In addition, it would be interesting to consider studies with multitemporal images to better delimit vegetation types and cultures that vary seasonally. Finally, field work is extremely important to validate the present map.

\section{REFERENCES}

BARbosA, C. C., CAMARA, G., MEdeIROS, J.S., CREPANI, E., NOVO, E. M. L. M., CORDEIRO, J. P. C. Operadores zonais em álgebra de mapas e sua aplicação a zoneamento ecológico-econômico. In: Simpósio Brasileiro de Sensoriamento Remoto, IX, 1998, Santos. Anais do Simpósio Brasileiro de Sensoriamento Remoto, 1998.

CÂNDIDO, L. A. Impacto da condição inicial de água no solo na previsão de verão da América do Sul. 2002. $224 \mathrm{f}$. Tese (Doutorado em Meteorologia) Instituto Nacional de Pesquisas Espaciais, São José dos Campos, 2002.

CAVALCANTI, A. C. Diagnóstico ambiental do município de Petrolina. Pernambuco: Embrapa-CNPS, ERP/NE, 1999. CHAMPEAUX, J. L., ARCOS, D., BAZILE, E., GIARD, D., GOUTORBE, J. P., HABETS, F., NOILHAN, J., ROUJEAN, J. L. AVHRR-derived vegetation mapping over Western Europe for use in numerical weather prediction models. International Journal of Remote Sensing, v. 21, p. 1183-1199, 2000. 
CLARK, D. B., XUE, Y., HARDING, R. J., VALDES. P. J. Modeling the Impact of Land Surface Degradation on the Climate of Tropical North Africa. Journal of Climate, v.14, p.1809-1822, 2001.

CUNHA, A. P. M. A., CANAVESI, V., VIEIRA, R. M. P., ALVALA, R. C. S. Validação do albedo da superfície terrestre obtido a partir de imagens do sensor modis em área de caatinga. In SIMPÓSIO INTERNACIONAL DE CLIMATOLOGIA, III , 2009, Canela. Anais do Simpósio Internacional de Climatologia. 2009.

DEFRIES, R. S., TOWSHEND, J. R. G., HANSEN, M. C. Continous fields of vegetation characteristics at the global scale at $1 \mathrm{~km}$ resolution. Journal of Geophysical Research, v. 104, n. D14, p. 16911-16923, 1999.

DORMAN, J. L., SELLERS, P.J.A. Global climatology of albedo, roughness length and stomatal resistance for atmospheric general circulation models as represented by the Simple Biosphere Model (SiB). Journal of Applied Meteorology, v. 28, p. 833-855, 1989.

EVA, H.D., BELWARD, A.S., MIRANDA, E., DI BELLA, C.M., GOND§, V., HUBER, O., JONES, S., SGRENZAROLI, M., FRITZ, S. A land cover map of South America. Global Change Biology, v.10, p. 731-744, 2004.

FENESSY, M. J. And XUE, Y. Impact of USGS vegetation map on GCM simulations over the United States. Ecological Applications, v. 7, n. 1, p. 22-33, 1997.

FINDELL, K. L., SHEVLIAKOVA, E. MILLY, P. C. D. AND STOUFFER, R. J. (Modeled impact of anthropogenic land cover change on climate. Journal of Climate, v. 20, n.14, 2007.

GAO, X.J., LUO, Y., LIN, W.T., ZHAO, Z.C., GIORGI, F. Simulation of effects of land use change on climate in China by a regional climate model. Advances in Atmospheric Sciences, v. 20, n. 4, p.583-592, 2003.

HALL, F.G., TOWSHEND, J.R., ENGMAN, E.T. Status of remote sensing algorithms for estimation of land surface state parameters. Remote Sensing of Environment, v.51, p.138-156, 1995.

HANSEN, M.C., DEFRIES, R,S., TOWNSHEND J.R.G., SOHLBERG R Global land cover classification at $1 \mathrm{~km}$ spatial resolution using a classification tree approach. International Journal of Remote Sensing, v.21, p.13311364, 2000.

HASTENRATH, S.; HELLER, L. Dynamics of climatic hazards in northeast Brazil, Quarterly Journal of the Royal Meteorological Society, v. 103, p. 77-92, 1977.

HASTENRATH, S. On modes of tropical circulation and climate anomalies. Journal of the Atmospheric Sciences, v. 35, p. 2222-2231, 1978.

HASTENRATH, S. Prediction of northeast Brazil rainfall anomalies, Journal of Climate, v. 3, p. 893- 904, 1990.
HASTENRATH, S.; GREISCHAR, L. Circulation mechanisms related to northeast Brazil rainfall anomalies, Journal of Geophysical Research, v. 98, 5093-5102, 1993.

HODGES, J. MOD12Q1 Land Cover Product Binary Data from Boston University. Disponível em $<\mathrm{http}$ ://duckwater.bu.edu/ lc/mod12q1.html. 2002>. Acesso em 24 outubro de 2010.

IBAMA (Centro de Sensoriamento Remoto). Monitoramento do desmatamento nos Biomas Brasileiros por satélites. Disponível em: <http://siscom.ibama.gov.br/ monitorabiomas/caatinga/caatinga.htm $>$. Acesso em 24 julho de 2010.

INSTITUTO BRASILEIRO DE GEOGRAFIA E ESTATÍSTICA- IBGE Mapa de vegetação do Brasil. Rio de Janeiro, 1993.

INSTITUTO BRASILEIRO DE GEOGRAFIA E ESTATÍSTICA- IBGE Mapa de biomas do Brasil e mapa de vegetação do Brasil, 2003. Disponível em: $<$ http://www. ibge.gov.br>. Acesso em 14 de agosto de 2004.

INSTITUTO BRASILEIRO DE GEOGRAFIA E ESTATÍSTICA- IBGE Censo agropecuário - 2006: Brasil, Grandes Regiões e Unidades da Federação. Disponível em: < http://www.ibge.gov.br >, Acesso em 25 de março de 2010.

KANG, H. S., XUE, Y., COLLATZ, G. J. Impact assessment of satellite-derived leaf area index datasets using a general circulation model. Journal of climate, v. 20, p. 993-1015, 2007.

KAYANO, M. T.; ANDREOLI, R. V. Relationship between rainfall anomalies over northeastern Brazil and the El NI'no - Southern Oscillation. Journal of Geophysical Research. v. 111, D13101, doi:10.1029/2005JD006142, 2006.

KOUSKY, V. E. Frontal influences on Northeast Brazil. Monthly Weather Review, v. 107, p. 1140-1153, 1979.

KOUSKY, V. E.; KAYANO, M. T.; CAVALCANTI, I. F. A. A review of the Southern Oscillation: Oceanic-atmospheric circulation changes and related rainfall anomalies, Tellus, Ser. A, 36, p.490-504, 1984.

KUCHLER, A. W. World map of natural vegetation. In: Mcnally, R. Goodes's world atlas. 16 th Edition, New York, USA, 16-17, 1983.

LAPOLA, D.M., OYAMA, M.D., NOBRE, C.A., SAMPAIO, G. A new world natural vegetation map for global change studies. Anais da Academia Brasileira de Ciências. 80, 2 [cited 2009-03-05], 397-408, 2008.

MATTHEWS, E. Global vegetation and land use: new highresolution data bases for climate studies. Journal of Applied Meteorology and Climatology, v. 22, p. 474-487, 1983.

MATTHEWS, E. Prescription of land-surface boundary conditions in GISS GCM II: a simple method based on highresolution vegetation data bases. National Aeronautic and Space Administration Technical Memorandum 86096. 1984. 
MMA/PROBIO. Levantamento da cobertura vegetal nativa Don uso do solo do Bioma Caatinga, 2007. Disponível em $<$ http:// mapas.mma.gov.br/mapas/aplic/probio/datadownload $>$. Acesso em 18 de dezembro de 2009.

MOURA, A. D.; SHUKLA, J. On the dynamics of droughts in northeast Brazil: Observations, theory and numerical experiments with a general circulation model. Journal of the Atmospheric Sciences. v. 38, p. 2653- 2675, 1981.

OLIVEIRA, G. S. Consequências climáticas da substituição gradual da floresta tropical amazônica por pastagem degradada ou por plantação de soja: um estudo de modelagem. 2008. 417 f. Tese (Doutorado em Meteorologia) - Instituto Nacional de Pesquisas Espaciais, São José dos Campos, 2008.

OYAMA, M. D. Consequências climáticas da mudança de vegetação no nordeste brasileiro: um estudo de modelagem. 2002. 220 f. Tese (Doutorado em Meteorologia) - Instituto Nacional de Pesquisas Espaciais, São José dos Campos, 2002.

OYAMA, M. D.; NOBRE, C.A. A simple potential vegetation model for coupling with the simple biosphere model (SIB), Revista Brasileira Meteorologia., v. 19, n. 2, p. 203-216, 2004.

RAMANKUTTY, N., FOLEY, J. A. Estimating historical changes in global land cover: croplands from 1700 to 1992. Global Biogeochemical Cycles, v.13, p. 997-1027, 1999.

RICHARDS, J. A. Remote Sensing Digital Image Analysis: An Introduction. New York: Springer-Verlag, 1995.

SELLERS, P. J., MINTZ, Y., SUD, Y.C., DALCHER, A.A. Simple Biosphere Model ( $\mathrm{SiB}$ ) for use within general circulation models. Journal of Atmospheric Sciences, v. 43, p. 505-531, 1986.

SESTINI, M. F., ALVALÁ, R. C. S., MELLO, E. M. K. et al. Elaboração de mapas de vegetação para utilização em modelos meteorológicos e hidrológicos. São José dos Campos: INPE, 2002.

SOUZA, D. C. and OYAMA, M. D. Climatic consequences of gradual desertification in the semiarid area of Northeast Brazil. Theoretical and Applied Climatology, v.103, p. 345-357, 2011.
SOUZA, E. B.; KAYANO, M. T.; TOTA, J.; PEZZI, L.; FISCH, G.; NOBRE, C. On the influences of the El Niño, La Niña and Atlantic dipole pattern on the Amazonian rainfall during 19601998, Revista Acta Amazonica, v. 30, p. 305-318, 2000. SOUZA, S. S., TOMASELLA J., GRACIA, M.G., MENEZES, P.C.P., AMORIN, M.C., PINTO, C.A.M. O Programa de Monitoramento Climático em Tempo Real na área de atuação da SUDENE : PROCLIMA. Boletim da Sociedade Brasileira de Meteorologia, v. 25, p. 15-24, 2001.

SOUZA, S. S. Impactos climáticos regionais da mudança de vegetação no semi-árido do Nordeste brasileiro. 2006. 209 f. Tese (Doutorado em Meteorologia) - Instituto Nacional de Pesquisas Espaciais, São José dos Campos, 2006.

SUD, Y. C., YANG, R., WALKER, G. K. Impact of in situ deforestation in Amazon on the regional climate: general circulation model simulation study. Journal of Geophysical Research, v. 101, p. 7095-7109, 1996.

TAYLOR, C. M., LAMBIN, E. F., STEPHENNE, N., HARDING, R. J., ESSERY, R. L. H. The Influence of Land Use Change on Climate in the Sahel. Journal of Climate, v. 15, p. 3615-3629, 2002.

VELOSO, H. P., RANGEL FILHO, A. L., LIMA, J. C. A. Classificação da vegetação brasileira, adaptada a um sistema universal, Rio de Janeiro: IBGE. 1991.

WILSON, M. F., HENDERSON SELLERS, A. A. Global archive of land cover and soils data for use in general circulation climate models. Journal of Climate, v. 5, p. 119-143, 1985.

XUE,Y., SELlERS, P. J., KINTER, J. L., SHUKLA, J. A simplified biosphere model for global climate studies. Journal of Climate, v. 4, p. 345-364, 1991.

XUE, Y., SHUKLA, J. The influence of land surface properties on Sahel climate. Part I: Desertification. Journal of Climate, v. 6, n. 12, p. 2232-2245, 1993.

XUE, Y., H., JUANG, M. H., LI, W. P., PRINCE, S., DEFRIES, W. P., JIAO, Y., VASIC, R. Role of land surface processes in monsoon development: East Asia and West Africa. Journal of Geophysical Research, v. 109, n. D03105, doi:10.1029/2003JD003556. 2004. 